\title{
A GALVANIC CELL WITH MOLTEN LITHIUM NITRATE*
}

\author{
A. J. Arvía, A. J. Calandra and M. E. Martins \\ Instituto Superior de Investigaciones, Facultad de Química y Farmacia and \\ División Ingenieria Química, Facultad de Ciencias Fisicomatematicas, \\ Universidad Nacional de La Plata, La Plata, Argentina
} Abstract-A galvanic cell comprising a molten lithium/lithium-ion electrode and a nitrate electrode
has been obtained. It can be represented by the following scheme:

$$
\mathrm{Li}(\mathrm{l}) / \mathrm{LiNO}_{2}(\mathrm{l}) / \mathrm{NO}_{2}(\mathrm{~g}), \mathrm{O}_{2}(\mathrm{~g}) / \mathrm{Pt} \text {. }
$$

Cell formation occurs when the molten lithium nitrate is electrolysed between platinum electrodes. The emf of the cell and its temperature dependence are in good agreement with thermodynamic calculations based on thermal data.

Zusammenfassung-Eine galvanische Zelle, bestehend aus einer Elektrode aus geschmolzenem Lithium/Lithium(I) und einer Nitrat-Elektrode wurde untersucht. Sie kann folgenderweise dargestelit werden:

$$
\mathrm{Li}(\mathrm{l}) / \mathrm{LiNO}_{3}(\mathrm{l}) / \mathrm{NO}_{2}(\mathrm{~g}), \mathrm{O}_{2}(\mathrm{~g}) / \mathrm{Pt} \text {. }
$$

Die Zelle wird durch Elektrolyse des geschmolzen, Lithiumnitrats zwischen Platinelektroder gebildet. Die EMK der Zelle und der Temperaturkoeffizient stimmen befriedigend mit den Ergebnissen der thermodynamischen Berechnung überein.

Résumé-Une cellule galvanique a été obtenue consistant en une électrode de lithium/ion-lithium et d'une électrode de nitrate. Elle peut être exprimée par le schéma suivant:

$$
\mathrm{Li}(\mathrm{l}) / \mathrm{LiNO}(\mathrm{l}) / \mathrm{NO}_{2}(\mathrm{~g}), \mathrm{O}_{2}(\mathrm{~g}) / \mathrm{Pt} \text {. }
$$

La cellule est formée par l'électrolyse du nitrate de lithium fondu entre des électrodes de platine. La FEM de la cellule et son coefficient de température sont en bonne concordance avec les résultats du calcul thermodynamique basé sur des données thermiques.

\section{INTRODUCTION}

WHEN molten sodium or silver nitrate are electrolysed with platinum electrodes, galvanic cells are formed due to the accumulation of products yielded by the electrochemical reactions, and their emf can be measured after the interruption of the current. ${ }^{1.2}$ Those residual cells are easily reproducible and stable. They are galvanic cells without liquid junction, corresponding to the equilibrium

$$
\mathrm{X}+\mathrm{NO}_{2}+\frac{1}{2} \mathrm{O}_{2}=\mathrm{XNO}_{3}
$$

where $\mathrm{X}$ is either sodium or silver. The galvanic cell comprises one electrode reversible to the cation and another reversible to the anion. Experimental and theoretical results for both galvanic cells agree very well in a range of temperature from the melting point of the salt to some $100^{\circ}$ upwards.

The present work is based on previous experience with the nitrate reversible electrode, the reproducibility of which has been demonstrated, ${ }^{2,3}$ and deals with the thermodynamics of a molten lithium nitrate reversible cell, involving the type of equilibrium already mentioned.

\footnotetext{
* Manuscript received 18 September 1965.
} 


\section{EXPERIMENTAL}

The cell consisted of a Pyrex glass container and two electrodes. The latter were made of platinum wires fixed inside glass compartments where a controlled gaseous atmosphere could be achieved. Those compartments had a number of holes at the bottom dipped into the electrolyte, which ensured a good electrical contact and a relatively low internal resistance. The electrodes were prepared as described in earlier work. The lithium/lithium-ion electrode formed in one of the compartments was kept under a nitrogen atmosphere.

Lithium nitrate was prepared from lithium carbonate, analytical reagent, BDH and nitric acid, analytical reagent, Riedel-de-Häen. The salt was recrystallized and later carefully dried in a vacuum system. The elimination of water was finally achieved by evacuation of the salt at temperatures above its melting point.

The anhydrous salt in the molten state was placed into the cell which was already in the thermostat at the chosen temperature. Prior to the electrolysis for forming the galvanic cell, the electrolyte was saturated with highly purified nitrogen. Finally the salt was electrolysed at current intensities ranging from 20 to $70 \mathrm{~mA}$. Conventional circuitry was used.

When the electrolysis was interrupted the potential of the residual cell was read with a Houston DC Potentiometric Voltmeter, Model HB-160, with a $10 \mathrm{M} \Omega$ impedance input and 0.3 per cent accuracy.

Taking into account the region where the nitrate electrode is reliable and shows the highest degree of reproducibility, as well as the $\mathrm{mp}$ and decomposition temperature of lithium nitrate, ${ }^{4}$ experiments were performed in the range of temperature from 260 to $370^{\circ} \mathrm{C}$. The temperature of the system was within $\pm 0.5^{\circ} \mathrm{C}$; it was read with a thermocouple hot junction placed in the cell.

\section{RESULTS}

The total reaction occurring in the cell during the electrolysis is

$$
\mathrm{LiNO}_{3}=\mathrm{Li}+\mathrm{NO}_{2}+\frac{1}{2} \mathrm{O}_{2} \text {. }
$$

The molten metal formed on the platinum cathode is trapped in the cathodic compartment, because it is lighter than the melt. The gases formed in the anodic section satisfy the stoichiometry indicated by (2). At the working temperatures nitrogen dioxide is partially dissociated into nitric oxide and oxygen,

$$
\mathrm{NO}_{2}=\mathrm{NO}+\frac{1}{2} \mathrm{O}_{2}
$$

the equilibrium constant for this reaction is $0.918 \times 10^{-1}$ at $600^{\circ} \mathrm{K}^{5}$

The galvanic cell formed after the interruption of the electrolysis attained a steady emf, the latter being independent of the electrolysis current. The steady potential was reached about $\frac{1}{2}$ min after the interruption of the current and it kept constant for at least $30 \mathrm{~min}$. The reversible nature of the residual cell was shown by the change of the emf when positive or negative pulses of the order of $1 \mathrm{~ms}$ were applied to the cell. When the pulses ceased, the emf recovered in a few seconds the original value.

The set-up used in the present work involved an internal resistance of about $10 \Omega$, so the potential read on the high input-impedance instrument was taken as the emf 
of the galvanic cell comprising the electrode reactions

and

$$
\mathrm{Li}(1)=\mathrm{Li}^{+}(1)+\mathrm{e}
$$

$$
\mathrm{NO}_{2}(\mathrm{~g})+\frac{1}{2} \mathrm{O}_{2}(\mathrm{~g})+\mathrm{e}=\mathrm{NO}_{3}-(\mathrm{l}) \text {. }
$$

Average values of the emf, $E$, obtained at different temperatures, $T$, are assembled in Table 1. $\left(E^{\circ}\right)_{\exp }$ is the standard emf of the cell:

By Nernst's equation,

$$
\mathrm{Li}(\mathrm{l}) / \mathrm{LiNO}_{3}(\mathrm{l}) / \mathrm{NO}_{2}(\mathrm{~g}), \mathrm{O}_{2}(\mathrm{~g}) / \mathrm{Pt} \text {. }
$$

$$
\left(E^{\circ}\right)_{\exp }=E-\frac{R T}{F} \ln p_{\mathrm{NO}_{2}} \times p_{\mathrm{O}_{2}}^{1 / 2} .
$$

$\left(E^{\circ}\right)_{\text {exp }}$ was calculated taking unit activity for the pure salt and the partial pressures of nitrogen dioxide and oxygen in the actual cell as $\frac{2}{3}$ and $\frac{1}{3}$ respectively.

Table 1. Experimental emf

\begin{tabular}{ccc}
\hline $\begin{array}{c}\text { Temp } \\
{ }^{\circ} \mathrm{C}\end{array}$ & $\begin{array}{c}E \\
\mathrm{~V}\end{array}$ & $\begin{array}{c}\left(E^{\circ}\right)_{\text {exp }} \\
\text { V }\end{array}$ \\
\hline $284 \pm 0.5$ & $3.66 \pm 0.025$ & $3.70 \pm 0.025$ \\
293 & 3.65 & 3.69 \\
303 & 3.63 & 3.68 \\
311 & 3.60 & 3.65 \\
312 & 3.58 & 3.63 \\
325 & 3.57 & 3.62 \\
358 & 3.51 & 3.56 \\
358 & 3.52 & 3.57 \\
371 & 3.47 & 3.52 \\
376 & 3.46 & 3.51 \\
\hline
\end{tabular}

\section{DISCUSSION}

As the total reaction involved in the galvanic cell is the formation of lithium nitrate from metallic lithium, nitrogen dioxide and oxygen, it is possible to evaluate the standard emf at the temperature of the experiments, using

$$
E^{\circ}=\frac{-\Delta F_{\mathrm{r}, \mathrm{T}}^{\circ}}{z F}
$$

and

$$
\Delta F_{\mathrm{r}, \mathrm{T}}^{\circ}=\Delta H_{\mathrm{r}, \mathrm{T}}^{\mathrm{o}}-T \Delta S_{\mathrm{r}, \mathrm{T}}^{\circ},
$$

where $\Delta F_{\mathrm{rT}}^{\circ}, \Delta H_{\mathrm{r}, \mathrm{T}}^{\circ}$ and $\Delta S_{\mathrm{r}, \mathrm{T}}^{\circ}$ are respectively the free energy, enthalpy and entropy increases at temperature $T$ for the formation of lithium nitrate in the chemical cell (I) and $z$ and $F$ have the usual meanings.

The standard entropy of formation of lithium nitrate is not available, but it can be estimated by the application of Berthelot's.principle; as recently indicated, this estimation yields values which on the average differ 0.76 e.u. from the experimental, without the volume correction. ${ }^{6}$ Accordingly, data from the literature allow the calculation of the standard entropy of formation of lithium nitrate from either

or

$$
\mathrm{NaNO}_{3}(\mathrm{~s})+\mathrm{Li}(\mathrm{s})=\mathrm{LiNO}_{3}(\mathrm{~s})+\mathrm{Na}(\mathrm{s})
$$

$$
\mathrm{NaF}(\mathrm{s})+\mathrm{LiNO}_{3}(\mathrm{~s})=\mathrm{LiF}(\mathrm{s})+\mathrm{NaNO}_{3}(\mathrm{~s}) .
$$


Both reactions yield $\left(S_{298}^{\circ}\right)_{\mathrm{LINO}_{3}}=22 \cdot 3$ e.u. Hence, the standard emf of the galvanic cell (I) is obtained by means of (7) and (8) at three temperatures above the melting point of the salt. Data required for the calculation ${ }^{7,8}$ are assembled in Table 2 . The calculated values of emf $\left(E^{\circ}\right)_{\text {cal }}$, are in Table 3. The agreement of the experimental and calculated emfs, and of their temperature dependence, is good and confirms the reaction assumed for the galvanic cell.

Table 2. Thermodynamic Data

\begin{tabular}{|c|c|c|c|c|c|c|}
\hline & $\begin{array}{l}S_{\text {898 }}^{\circ} \\
\text { e.u. }\end{array}$ & & $\begin{array}{c}\Delta H_{298}^{\circ} \\
\mathrm{cal} / \mathrm{mole}\end{array}$ & $\begin{array}{c}H_{800}-H_{298} \\
\text { cal/mole }\end{array}$ & $\begin{array}{l}S_{298}^{\circ} \\
\text { e.u. }\end{array}$ & $\begin{array}{c}S_{B 00}-S_{29 B} \\
\text { e.u. }\end{array}$ \\
\hline $\begin{array}{l}\mathrm{Na} \\
\mathrm{NaNO}, \\
\mathrm{LiF} \\
\mathrm{NaF}\end{array}$ & $\begin{array}{c}12 \cdot 2 \\
27 \cdot 8 \\
8 \cdot 57 \\
14 \cdot 0\end{array}$ & $\begin{array}{l}\mathrm{Li} \\
\mathrm{O}_{2} \\
\mathrm{NO}_{2} \\
\mathrm{LiNO}_{3}\end{array}$ & $\begin{array}{c}- \\
\overline{8091} \\
-115279\end{array}$ & $\begin{array}{r}2765 \\
2210 \\
3015 \\
13490\end{array}$ & $\begin{array}{r}6 \cdot 70 \\
49 \cdot 00 \\
57 \cdot 47\end{array}$ & $\begin{array}{r}6 \cdot 26 \\
5 \cdot 10 \\
6 \cdot 90 \\
28 \cdot 49\end{array}$ \\
\hline
\end{tabular}

table 3. Calculated emf

\begin{tabular}{ccc}
\hline${ }^{2} \mathrm{Kemp}$ & ${ }^{{ }^{\circ} \mathrm{C}}$ & $\left.{ }^{\circ}\right)_{\text {eal }}$ \\
\hline 525 & 252 & 3.805 \\
550 & 277 & 3.747 \\
600 & 327 & 3.670 \\
\hline
\end{tabular}

Acknowledgements-This work was done with partial financial assistance of the Consejo Nacional de Investigaciones Cientfficas y Técnicas, Argentina. A. J. C. thanks the CNICT for the fellowship granted, and M.E. M. for the scholarship granted by the Facultad de Ciencias Fisicomatematicas de la Universidad de La Plata.

\section{REFERENCES}

1. A. J. Arvif, A. J. Calandra and W. E. Truaca, Electrochim. Acto 9, 1417 (1964).

2. W. E. TriacA and A. J. ARviA, Electrochim. Acta 9, 919 (1964).

3. J. A. A. KetelaAar and A. Dammers-De Klerk, Recl. Trav. Chim. Pays-Bas Belg. 83, 322 (1964).

4. P. PAsCaL, Traité de Chemie Minérale, Vol. VI, p. 769. Masson, Paris (1933).

5. A. P. Altshuller, J. phys. Chem. 61, 251 (1957).

6. N. N. Drozin, Zh. fiz. Khim. 38, 2551 (1964); Chem. Abstr. 56, 76f (1965).

7. Selected Values of Chemical Thermodynamic Properties. National Bureau of Standards, Circular 500 (1952).

8. K. K. Ket.LY, Contribution to the Data on Theoretical Metallurgy-XIII. High Temperature Heat Content, Heat Capacity and Entropy Data for the Elements and Inorganic Compounds. Bull. 584. Bureau of Mines, U.S.A. 